\title{
Knockdown of Interleukin-1 Receptor Type-1 on Endothelial Cells Attenuated Stress-Induced Neuroinflammation and Prevented Anxiety-Like Behavior
}

\author{
Eric S. Wohleb, ${ }^{1,2}$ Jenna M. Patterson, ${ }^{2}$ Vikram Sharma, ${ }^{2}$ Ning Quan, ${ }^{1,3}$ Jonathan P. Godbout, ${ }^{2,3,4}$ \\ and John F. Sheridan ${ }^{1,3,4}$ \\ ${ }^{1}$ Oral Biology Division, ${ }^{2}$ Department of Neuroscience, ${ }^{3}$ Institute for Behavioral Medicine Research, and ${ }^{4}$ Center for Brain and Spinal Cord Repair, The Ohio \\ State University, Columbus, Ohio 43210
}

Interleukin-1 $\beta$ (IL-1 $\beta)$ is an inflammatory cytokine that plays a prominent role in stress-induced behavioral changes. In a model of repeated social defeat (RSD), elevated IL-1 $\beta$ expression in the brain was associated with recruitment of primed macrophages that were necessary for development of anxiety-like behavior. Moreover, microglia activation and anxiety-like behavior associated with RSD did not occur in IL-1 receptor type-1 knock-out (IL-1R $1^{\mathrm{KO}}$ ) mice. Therefore, the objective of this study was to examine the role of IL-1 signaling in RSD-induced macrophage trafficking to the brain and anxiety-like behavior. Initial studies revealed that RSD did not increase circulating myeloid cells in IL-1R $1{ }^{\mathrm{KO}}$ mice, resulting in limited macrophage trafficking to the brain. In addition, IL-1R ${ }^{\mathrm{KO}}$ bone marrowchimera mice showed that IL-1R1 expression was essential for macrophage trafficking into the brain. To differentiate cellular mediators of stress-induced IL-1 signaling, endothelial-specific IL-1R1 knock-down (eIL-1R1kd) mice were used. Both wild-type (WT) and eIL$1 \mathrm{R} 1 \mathrm{kd}$ mice had increased circulating monocytes, recruitment of macrophages to the brain, and altered microglia activation after RSD. Nonetheless, RSD-induced expression of IL-1 $\beta$, TNF- $\alpha$, and IL-6 mRNA in brain CD11b ${ }^{+}$cells was attenuated in eIL-1R1kd mice compared with WT. Moreover, anxiety-like behavior did not develop in eIL-1R1kd mice. Collectively, these findings demonstrated that there was limited RSD-induced priming of myeloid cells in IL-1R ${ }^{\mathrm{KO}}$ mice and disrupted propagation of neuroinflammatory signals in the brain of eIL-1R1kd mice. Furthermore, these data showed that transduction of IL-1 signaling by endothelial cells potentiates stressinduced neuroinflammation and promotes anxiety-like behavior.

Key words: anxiety; blood-brain barrier; interleukin-1; microglia; neuroinflammation; stress

\section{Introduction}

Interleukin- $1 \beta(\mathrm{IL}-1 \beta)$ is a proinflammatory cytokine that mediates mood disturbances and cognitive deficits after psychological stress (Goshen and Yirmiya, 2009). Several cell types may contribute to stress-induced IL- $1 \beta$ production in the brain, including resident microglia, perivascular macrophages, and endothelial cells (Allan et al., 2005). Depending on the properties of neuroimmune activation, microglia, macrophages, and endothelial cells respond dynamically to propagate and secrete proinflammatory cytokines and secondary mediators, leading to neuroinflammation (Ching et al., 2007; Serrats et al., 2010).

Received Aug. 30, 2013; revised Dec. 10, 2013; accepted Jan. 6, 2014.

Author contributions: E.S.W., N.Q., J.P.G., and J.F.S. designed research; E.S.W., J.M.P., and V.S. performed research; N.Q. contributed unpublished reagents/analytic tools; E.S.W., J.M.P., V.S., J.P.G., and J.F.S. analyzed data; E.S.W., N.Q., J.P.G., and J.F.S. wrote the paper.

This research was supported by National Institute of Mental Health Grants R01-MH-093473 and R01-MH-097243 (J.F.S.) and Predoctoral Fellowship F31-MH09547301 (E.S.W.) and National Institute on Aging Grant R01-AG033028 (J.P.G.). We thank Brenda Reader and Daniel Shea for their technical assistance.

The authors declare no competing financial interests.

Correspondence should be addressed to John F. Sheridan and Jonathan P. Godbout, 223 Institute for Behavioral Medicine Research Building, 460 Medical Center Drive, Columbus, OH 43210. E-mail: John.Sheridan@osumc.edu, Jonathan.Godbout@osumc.edu.

DOI:10.1523/JNEUROSCI.3723-13.2014

Copyright $\odot 2014$ the authors $\quad 0270-6474 / 14 / 342583-09 \$ 15.00 / 0$
These neuroimmune responses provoked by stress-induced IL- $1 \beta$ are pertinent because they are implicated in neuronal adaptations underlying anxiety- and depressive-like behaviors (Koo et al., 2010; Christoffel et al., 2011; Eyre and Baune, 2012; Tanaka et al., 2012). Thus, targeting IL- $1 \beta$ production may have beneficial therapeutic effects in stress-induced mood disorders (Koo and Duman, 2009).

Several reports indicate that inescapable footshock or restraint stress promotes microglia activation and increased brain IL- $1 \beta$ levels (Johnson et al., 2005; Blandino et al., 2009; Tynan et al., 2010), but it is unclear how these neuroimmune alterations influence behavior. In comparison, the psychosocial stress model of repeated social defeat (RSD) promotes brain region-specific activation of brain $\mathrm{CD} 11 \mathrm{~b}^{+}$cells (microglia/macrophages) that leads to prolonged anxiety-like behavior (Wohleb et al., 2011). In addition, peripheral myeloid $\left(\mathrm{CD}_{11 b^{+}}\right)$cells are responsive to RSD-induced neuroendocrine activation and develop a primed, glucocorticoid (GC)-insensitive phenotype after RSD (Stark et al., 2001; Avitsur et al., 2005; Engler et al., 2005; Bailey et al., 2009). Recent findings indicate that recruitment of these primed monocytes to the brain is critical in development of RSD-induced anxiety (Wohleb et al., 2011, 2013). In the context of RSD, IL-1 signaling plays a key role in central and peripheral alterations in 
immunity. For instance, IL-1 receptor type-1 knock-out (IL$1 \mathrm{R} 1^{\mathrm{KO}}$ ) mice do not develop primed, GC-insensitive myeloid cells in the periphery (Engler et al., 2008). Moreover, lack of IL-1R1 blocked microglia activation and development of anxietylike behavior in response to RSD (Wohleb et al., 2011). Although these findings indicate that IL- $1 \beta$ plays a significant role in RSDinduced neuroinflammation and anxiety, the cellular mechanisms that mediate these effects remain undefined.

The primary objective of this study was to determine the role of IL-1 signaling in RSD-induced macrophage trafficking to the brain and anxiety-like behavior. The present study showed that RSD-induced redistribution of peripheral monocytes was impaired in IL-1R1 ${ }^{\mathrm{KO}}$ mice, which was associated with limited macrophage trafficking to the brain and reduced microglia activation after RSD. In mice with cell-specific knockdown of IL-1R1 on endothelial cells (eIL-1R1kd) RSD primed peripheral monocytes caused recruitment of macrophages to the brain and increased the presence of de-ramified microglia in the brain. Despite these indications of neuroinflammation, enriched brain $\mathrm{CD} 11 \mathrm{~b}^{+}$cells from eIL-1R1kd mice had significantly reduced IL- $1 \beta$, TNF- $\alpha$, and IL-6 mRNA levels, which corresponded with decreased anxiety-like behavior in response to RSD. Collectively, these data indicated that endothelial cells are critical transducers of macrophage-derived signals that promote stress-induced neuroinflammation and anxiety-like behavior.

\section{Materials and Methods}

Mice. Male C57BL/6 (6-10 weeks old) and CD-1 (12 months old) mice were purchased from Charles River and allowed to acclimate to their surroundings for 7-10 d before initiation of any experimental procedures. C57BL/6-Tg (CAG-EGFP) $131 /$ leysopJ (catalog \#006567) were purchased from The Jackson Laboratory. IL-1R1 ${ }^{\mathrm{KO}}$ mice on the C57BL/6 background and eIL-1R1kd on the FVB background were obtained from colonies maintained by Dr. Ning Quan at Ohio State University (Columbus, OH). IL-1R1 ${ }^{\mathrm{KO}}$ mice were originally purchased from The Jackson Laboratory (catalog \#003245), and eIL-1R1kd mice were generated in Dr. Quan's laboratory (Li et al., 2011). Mice were housed in $11.5 \times 7.5 \times 6$ inch polypropylene cages. Rooms were maintained at $21^{\circ} \mathrm{C}$ under a $12 \mathrm{~h}$ light/dark cycle with ad libitum access to water and rodent chow. All procedures were in accordance with the National Institutes of Health Guidelines for the Care and Use of Laboratory Animals and were approved by Ohio State University Institutional Laboratory Animal Care and Use Committee.

$R S D$. Mice were subjected to RSD as described previously (Quan et al., 2003; Engler et al., 2005, 2008; Wohleb et al., 2013). In brief, an aggressive intruder male CD-1 mouse (retired breeder) was introduced into cages of established male cohorts (three per cage) of C57BL/6 mice for six consecutive nights between 5:00 P.M. and 7:00 P.M. (2 h). During each cycle, submissive behavior, including upright posture, fleeing, and crouching, were observed to ensure that the resident mice showed subordinate behavior. If the intruder did not initiate a defeat within 5-10 min or was defeated by any of the resident mice, then a new intruder was introduced. At the end of the $2 \mathrm{~h}$ period, the intruder was removed and the residents were left undisturbed until the following day when the paradigm was repeated. Different intruders were used on consecutive nights. The health status of the mice was carefully examined throughout the paradigm. Mice that were injured or moribund were removed from the study. Consistent with previous studies, $<5 \%$ of mice met the early removal criteria. Control $(\mathrm{CON})$ mice were left undisturbed in their home cages until they were killed.

Anxiety-like behavior. Anxiety-like behavior was determined using open-field activity and light/dark preference tests as described previously (Wohleb et al., 2011; Hanke et al., 2012). For the open-field test, mice were placed in the corner of the test apparatus $(40 \times 40 \times 25 \mathrm{~cm}$ Plexiglas box), and activity was recorded for $5 \mathrm{~min}$. Mice with anxiety-like behavior enter the center of the open-field more slowly and spend less time in the open field. For light/dark preference, the Plexiglas test apparatus $(40 \times 40 \times 25 \mathrm{~cm})$ was divided into equal zones (i.e., light or dark zones) with a doorway connecting the two sides. The dark zone was enclosed and had significantly less light ( $<3$ lux). To initiate testing, mice were placed into the light side, and activity was recorded for $5 \mathrm{~min}$. Anxious mice enter the dark zone faster and spend more time in the dark zone. Both tests were recorded and analyzed using an automated system (AccuScan Instruments).

$\mathrm{GFP}^{+}$bone marrow-chimera. Bone marrow (BM)-chimeric mice were generated as described previously (Wohleb et al., 2013). In brief, recipient BM C57BL/6 male mice ( 6 weeks old) were injected intraperitoneally once daily for 2 consecutive days with busulfan in a 1:1 solution of DMSO and deionized $\mathrm{H}_{2} \mathrm{O}(30 \mathrm{mg} / \mathrm{kg}$ per $100 \mu \mathrm{l})$. This dose of busulfan was chosen to reduce morbidity and mortality associated with total ablation of the BM achieved by higher doses of the drug. Donor BM-derived cells were obtained from the femur of C57BL/6-Tg (CAG-EGFP) mice. BMderived cells $\left(1 \times 10^{6}\right)$ were transferred to recipient mice by tail vein injection $(100 \mu \mathrm{l}) 48 \mathrm{~h}$ after the second dose of busulfan. Mice were left undisturbed for 4 weeks to allow engraftment. Mice that had $<30 \% \mathrm{BM}$ engraftment were excluded from the study.

Isolation of brain $\mathrm{CD}_{11 b^{+}}$cells. $\mathrm{CD}_{11 \mathrm{~b}^{+}}$cells were isolated from whole-brain homogenates as described previously (Wohleb et al., 2013). In brief, brains were passed through a $70 \mu \mathrm{m}$ cell strainer. Homogenates were centrifuged at $600 \times g$ for $6 \mathrm{~min}$. Supernatants were removed and cell pellets were resuspended in 70\% isotonic Percoll (GE Healthcare). A discontinuous Percoll density gradient was layered as follows: 50, 35, and $0 \%$ isotonic Percoll. The gradient was centrifuged for $20 \mathrm{~min}$ at $2000 \times \mathrm{g}$, and cells were collected from the interphase between the 70 and $50 \%$ Percoll layers. These cells were referred to as enriched brain CD11b ${ }^{+}$ cells based on previous studies demonstrating that viable cells isolated by

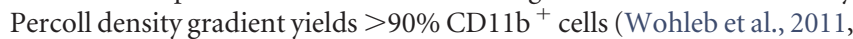
2012).

Isolation of blood leukocytes. Whole blood was collected with EDTAlined syringes by cardiac puncture immediately after $\mathrm{CO}_{2}$ asphyxiation. Red blood cells were lysed, samples were washed, and total number of leukocytes was determined with the BD Coulter Particle Count and Size Analyzer (Beckman Coulter).

Splenocyte cell culture. Spleens were removed from mice and homogenized using Seward Stomacher 80 Biomaster system to obtain single-cell suspensions. Cells were passed through a $70 \mu \mathrm{m}$ filter, washed with PBS, and resuspended in magnetic-activated cell sorting buffer. CD11b ${ }^{+}$ splenocytes were enriched with magnetic separation using CD11b microbeads (catalog \#130-049-601; Miltenyi Biotec). After separation, total $\mathrm{CD}_{11 \mathrm{~b}}{ }^{+}$cell number was determined with the BD Coulter Particle Count and Size Analyzer. Cells were resuspended in warm media (DMEM supplemented with 10\% FBS, $3.7 \mathrm{~g} / \mathrm{L}$ sodium bicarbonate, 200 mm glutamine, $100 \mathrm{U} / \mathrm{ml}$ penicillin $\mathrm{G}$, and $100 \mu \mathrm{g} / \mathrm{ml}$ streptomycin) and plated at 250,000 cells per well in 12-well plates. Cells were then stimulated with sterile saline or $10 \mu \mathrm{g} / \mathrm{ml}$ lipopolysaccharide (LPS serotype 0127:B8; Sigma). After $18 \mathrm{~h}$, cell mRNA was collected for gene expression analyses.

Corticosterone enzyme immunoassay assay. Plasma concentrations of corticosterone were determined using the Corticosterone EIA kit from Enzo Life Science according to the instructions of the manufacturer (ADI-900-097). Absorbance was read at $405 \mathrm{~nm}$ using a Spectramax Plus $^{384}$ (Molecular Devices).

Flow cytometry. Staining of cell surface antigens was performed as described previously (Wohleb et al., 2013). In brief, Fc receptors were blocked with anti-CD16/CD32 antibody (eBioscience). Cells were washed and then incubated with the appropriate antibodies [CD45, CD11b, CD14 (eBioscience) and Ly6C (BD Biosciences)] for $1 \mathrm{~h}$ at $4{ }^{\circ} \mathrm{C}$. Cells were washed and then resuspended in FACS buffer for analysis. Nonspecific binding was assessed using isotype-matched antibodies. Antigen expression was determined using a BD Biosciences FACSCaliber four-color cytometer. Data were analyzed using FlowJo software, and gating for each antibody was determined based on isotype-stained controls.

Immunofluorescence. Brains were collected from mice after transcardial perfusion with sterile PBS (PBS, pH 7.4, with EDTA) and 4\% form- 

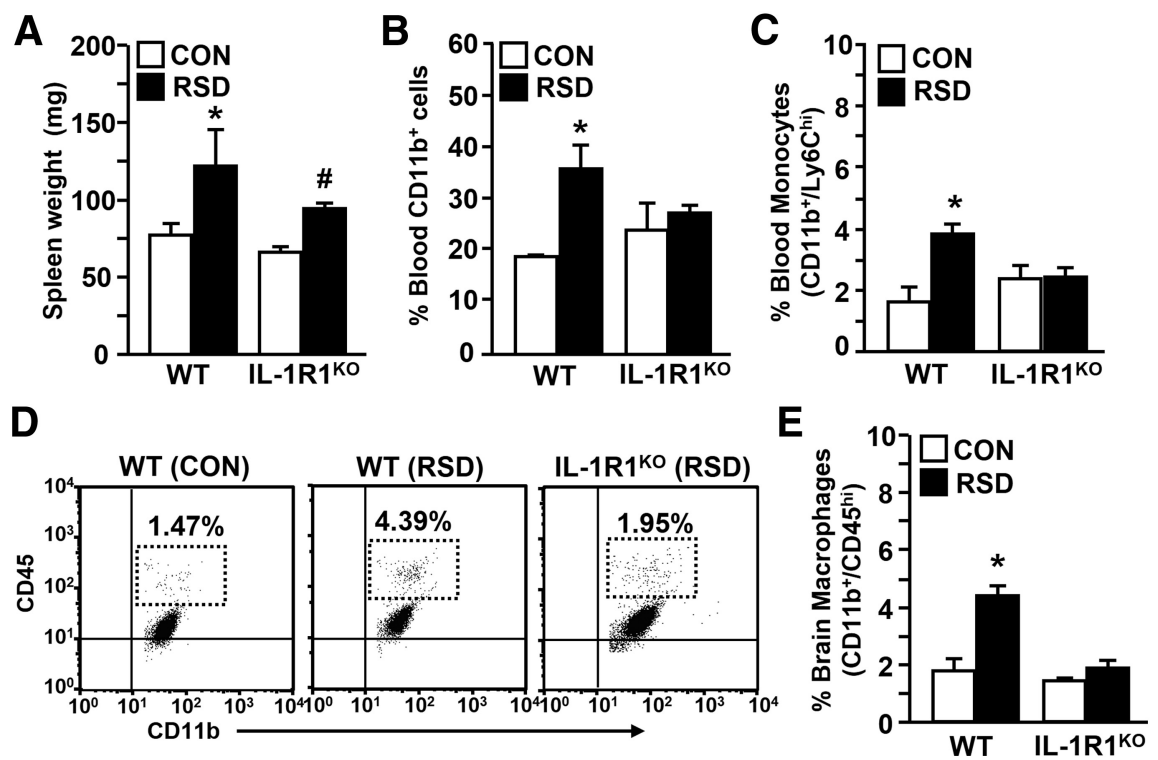

Figure 1. IL-1R $1^{\mathrm{K} 0}$ mice do not have increased myeloid cells in the blood and brain after RSD. WT and IL-1R1 ${ }^{\mathrm{K} 0} \mathrm{C} 57 \mathrm{BL} / 6$ mice were subjected to RSD or left undisturbed as CON mice. Spleen, blood, and brain CD11b ${ }^{+}$cells were collected $14 \mathrm{~h}$ after the final cycle of RSD. A, Average spleen weight. $B$, Average percentage of blood CD11b ${ }^{+}$cells. $C$, Average percentage of blood monocytes $\left(C D 11 b^{+} / L y 6 C^{\text {hi }}\right) . D$, Representative bivariate dot plots of CD11b/CD45 labeling in each experimental group. $\boldsymbol{E}$, Average proportion of brain macrophages (CD11 $\left.{ }^{+} / \mathrm{CD} 45^{\text {hi }}\right)$. Bars represent average \pm SEM. ${ }^{*} p<0.05$, different from CON; ${ }^{*} p<0.10$, different from CON.

aldehyde. Brains were postfixed in $4 \%$ formaldehyde for $24 \mathrm{~h}$ and incubated in $20 \%$ sucrose for an additional $24 \mathrm{~h}$. Fixed brains were frozen with isopentane $\left(-78^{\circ} \mathrm{C}\right)$ and sectioned $(20 \mu \mathrm{m})$ using a Microm HM550 cryostat. Brain regions were identified by reference markers in accordance with the stereotaxic mouse brain atlas (Paxinos and Franklin, 2008). To label for Iba-1 (ionized calcium binding adapter molecule-1), sections were placed free-floating in cryoprotectant until staining. Next, sections were washed in PBS with 1\% BSA, blocked with 2\% normal goat serum, and incubated with a rabbit anti-mouse Iba- 1 antibody (Wako Chemicals). Next, sections were washed in PBS with $1 \%$ BSA and incubated with a fluorochrome-conjugated secondary antibody (Alexa Fluor 594). Sections were mounted on slides, then coverslipped with Fluoromount (Beckman Coulter), and stored at $-20^{\circ} \mathrm{C}$. Fluorescent sections were visualized using an epifluorescent Leica DM5000B microscope. Images were captured using a Leica DFC300 FX camera and imaging software.

Proportional area analyses of Iba-1. To quantify the phenotypic changes of microglia, proportional area analyses of Iba-1 labeling was performed (Donnelly et al., 2009). Representative images (six to eight bilateral) were taken from each brain region at $20 \times$ magnification. A threshold for positive staining was determined for each image and was processed by densitometric scanning of the threshold targets using NIH ImageJ software. Proportional area was reported as the average percentage area in the positive threshold for all representative pictures.

Classification of $\mathrm{GFP}^{+}$cell phenotype. $\mathrm{GFP}^{+}$cells in the brain were quantified and classified as described previously (Vallières and Sawchenko, 2003; Wohleb et al., 2013). In brief, $\mathrm{GFP}^{+}$cells that had a rod, elongated, or round/amoeboid morphology were classified as rod/circular. Only $\mathrm{GFP}^{+}$cells that had distinct processes were classified as ramified (stellate). Because rod/circular $\mathrm{GFP}^{+}$cells colocalized with blood vessels, these $\mathrm{GFP}^{+}$cells were designated as perivascular. Moreover, ramified (stellate) $\mathrm{GFP}^{+}$cells were determined to be parenchymal because they colocalized with Iba-1 staining but did not colocalize with vasculature (Ly6C).

RNA isolation and real-time PCR. RNA was collected from cells using USB PrepEase RNA spin kit (Affymetrix) or tri-reagent/isopropanol precipitation. RNA was reverse transcribed to cDNA using the High Capacity cDNA Reverse Transcription kit (Applied Biosystems). Quantitative PCR was performed using the Applied Biosystems Assay-on-Demand Gene Expression protocol. In brief, experimental cDNA was amplified on an ABI PRISM 7300 sequence detection system (Applied Biosystems) by real-time PCR and normalized based on reference cDNA (GAPDH). Data were analyzed with comparative threshold cycle method.

Statistical analyses. Data were subjected to Shapiro-Wilk test using Statistical Analysis Systems (SAS) software. Observations more than three interquartile ranges from the first and third quartile were excluded from analyses. Significant main effects and interactions were determined using one-way (stress, genotype) or two-way (stress $\times$ genotype) ANOVA using the general linear model procedures of SAS. Differences between group means were evaluated with $t$ test using the least-significant difference procedure of SAS.

\section{Results}

RSD increased circulating monocytes and brain macrophages in wild-type mice but not IL-1R1 ${ }^{\mathrm{KO}}$ mice

Previous studies indicate that GCinsensitive myeloid $\left(\mathrm{CD} 11 \mathrm{~b}^{+}\right)$cells do not develop in IL-1R $1^{\mathrm{KO}}$ mice after RSD (Engler et al., 2008). Moreover, RSDinduced anxiety-like behavior was not evident in IL-1R ${ }^{\mathrm{KO}}$ mice (Wohleb et al., 2011). To determine whether deficits in RSD-induced priming of $\mathrm{CD}_{11 \mathrm{~b}^{+}}$cells were related to diminished anxiety responses in IL-1R1 ${ }^{\mathrm{KO}}$ mice, blood and enriched brain $\mathrm{CD}_{11 \mathrm{~b}^{+}}$cells were collected from wild-type (WT) and IL-1R $1^{\mathrm{KO}}$ mice subjected to RSD or left undisturbed as controls. Fig. $1 A$ shows that RSD increased spleen weight in WT and IL-1R1 ${ }^{\mathrm{KO}}$ mice (main effect of stress; $F_{(1,19)}=$ $7.89, p<0.01)$. RSD-induced splenomegaly was associated with an increased proportion of blood $\mathrm{CD} 11 \mathrm{~b}^{+}$cells (stress $\times$genotype interaction; $F_{(1,21)}=4.48, p<0.04$; Fig. $1 B$ ) and monocytes (stress $\times$ genotype interaction; $F_{(1,19)}=8.22, p<0.01$; Fig. $1 C$ ) in WT but not IL-1R $1^{\mathrm{KO}}$ mice. Moreover, RSD caused significant recruitment of macrophages to the brain of WT mice, but macrophage trafficking was not increased in the brain of IL-1R1 KO mice after RSD (stress $\times$ genotype interaction; $F_{(1,26)}=13.41$, $p<0.001$; Fig. $1 D, E)$. These results indicate that lack of primed myeloid cells in circulation of IL-1R $1^{\mathrm{KO}}$ mice resulted in diminished macrophage trafficking in the brain after RSD.

\section{Expression of IL-1R1 is required for RSD-induced recruitment of myeloid cells to the brain of $\mathrm{GFP}^{+}$ BM-chimeric mice}

Recent work showed that RSD caused significant infiltration of macrophages into specific stress-responsive brain regions and that these cells are integral for development of anxiety-like behavior (Wohleb et al., 2013). To determine whether IL-1R1 expression on BM-derived myeloid cells is required for RSDinduced macrophage trafficking to the brain, BM-chimera mice were generated by transfer of WT $\left(\mathrm{GFP}^{+}\right) \mathrm{BM}$ to WT or IL$1 \mathrm{R} 1{ }^{\mathrm{KO}}$ recipient mice. $\mathrm{BM}$-chimera mice were then subjected to RSD or left undisturbed as controls. Fig. $2 A$ shows that CON mice had minimal macrophage trafficking in the amygdala (AMYG), whereas RSD caused robust infiltration of $\mathrm{GFP}^{+}$perivascular and parenchymal macrophages (Fig. $2 B$ ). In contrast, RSD-induced infiltration of perivascular and parenchymal GFP ${ }^{+}$macrophages were not detected in the brain of IL-1R ${ }^{\mathrm{KO}}$ BM-chimera mice. 
Quantification of perivascular and parenchymal $\mathrm{GFP}^{+}$macrophages shows that RSD significantly increased macrophage infiltration in the prefrontal cortex $\left(\right.$ PFC; $F_{(1,15)}=6.13, p<0.03$; Fig. $\left.2 D\right)$, $\operatorname{AMYG}\left(F_{(1,15)}=6.20, p<0.03\right.$; Fig. $\left.2 E\right)$, and hippocampus (HPC) $\left(F_{(1,15)}=2.46\right.$, $p=0.10$; Fig. $2 F)$ of WT recipient mice but not in IL-1R $1{ }^{\mathrm{KO}}$ recipient mice. In addition, analysis of Iba-1 proportional area showed that macrophage trafficking in WT mice was associated with enhanced microglia hypertrophy and de-ramification in the $\operatorname{PFC}\left(F_{(1,17)}=10.74, p<0.006\right.$; Fig. $\left.2 G\right)$, $\operatorname{AMYG}\left(F_{(1,17)}=28.99, p<0.0001\right.$; Fig. $2 H$ ), and HPC-dentate gyrus (DG; $F_{(1,17)}=$ 93.50, $p<0.0001$; Fig. 2I) of WT recipient mice. Although there was a robust change in the morphology of microglia in WT mice after RSD, these changes were not observed in IL-1R1 ${ }^{\mathrm{KO}}$ recipient mice (stress $\times$ genotype interaction, $p<0.0001$ for each region). These findings indicate that restoration of IL-1R1 expression on BM-derived cells is insufficient to promote RSD-induced macrophage trafficking in the brain. Furthermore, these data indicate that region-specific microglia activation after RSD is dependent on IL-1R1 expression.

\section{RSD increased spleen weight and circulating monocytes in eIL-1R1kd mice}

In the brain, endothelial cells express high levels of IL-1R1 and play an important role in the propagation of neuroimmune signals (Quan and Banks, 2007). Thus, eIL-1R1kd mice were used to further elucidate the role of IL-1 signaling in RSDinduced neuroinflammation and anxiety. Endothelial cell-specific knockdown of IL-1R1 was performed by antisense expression driven by the Tie-2 promoter, which is selectively expressed by endothelial cells during adulthood (Ohtsuki et al., 2005; Li et al., 2011). During initial studies WT and eIL-1R1kd mice were subjected to RSD or left undisturbed as CON mice to determine whether eIL-1R1kd mice had characteristic RSD-induced immune alterations. Fig. $3 A$ shows that RSD increased spleen weight in WT and eIL-1R1kd mice $\left(F_{(1,75)}=54.87, p<0.0001\right)$. In addition, plasma levels of corticosterone were increased in WT and eIL-1R1kd mice immediately after $\operatorname{RSD}\left(F_{(1,19)}=58.54, p<0.0001 ;\right.$ Fig. $\left.3 B\right)$. Moreover, RSD increased the proportion of blood CD11b ${ }^{+}$cells $\left(F_{(1,34)}=\right.$ 37.03, $p<0.0001$; Fig. $3 C)$ and monocytes $\left(F_{(1,32)}=6.64, p<\right.$ 0.02; Fig. $3 D, E)$ in both WT and eIL-1R1kd mice after RSD. Peripheral $\mathrm{CD} 11 \mathrm{~b}^{+}$cells also demonstrated a primed phenotype after RSD with increased production of proinflammatory cytokines after LPS stimulation (Bailey et al., 2009). Thus, CD11b ${ }^{+}$ splenocytes were isolated from WT or eIL-1R1kd mice and then stimulated with saline ( - ) or the bacterial component $(+)$. Table 1 shows that RSD or LPS alone significantly increased IL- $1 \beta$, TNF- $\alpha$, and IL- 6 mRNA levels in cultured CD1 $1 \mathrm{~b}^{+}$splenocytes $\left(p<0.02\right.$, for each). RSD-induced priming of $\mathrm{CD} 11 \mathrm{~b}^{+}$spleno- cytes was evident because LPS stimulation significantly exaggerated mRNA expression of IL- $1 \beta$, TNF- $\alpha$, and IL- 6 (stress $\times$ LPS interaction; $p<0.05$, for each). These findings indicate that RSDinduced neuroendocrine responses and subsequent priming of peripheral myeloid cells were maintained in eIL-1R1kd mice.

RSD promoted recruitment of peripheral macrophages and altered microglia morphology in WT and eIL-1R1kd mice RSD-induced priming of peripheral myeloid cells promotes their trafficking into the brain, which contributes to neuroinflammation (Wohleb et al., 2011). To determine whether eIL-1R1kd had an influence on macrophage trafficking, enriched brain CD11b ${ }^{+}$ cells were collected. RSD caused significant macrophage trafficking to the brain of WT and eIL-1R1kd mice $\left(F_{(1,47)}=19.31, p<\right.$ $0.0001 ;$ Fig. $4 A, B)$. In addition, surface expression of the activation marker CD14 was significantly enhanced on macrophages $\left(F_{(1,32)}=6.73, p<0.01\right.$; Fig. $\left.4 C\right)$ and microglia $\left(F_{(1,32)}=21.78\right.$, $p<0.0001$; Fig. $4 D)$ in the brain after RSD.

In previous studies, robust macrophage recruitment to the brain coincided with the presence of de-ramified microglia in the PFC, paraventricular nucleus (PVN), AMYG, and HPC (Wohleb 
A

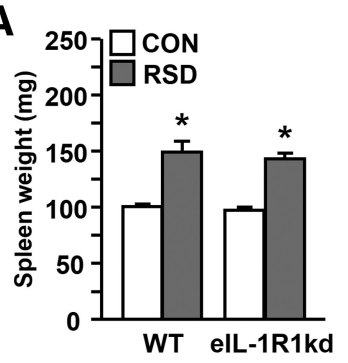

B

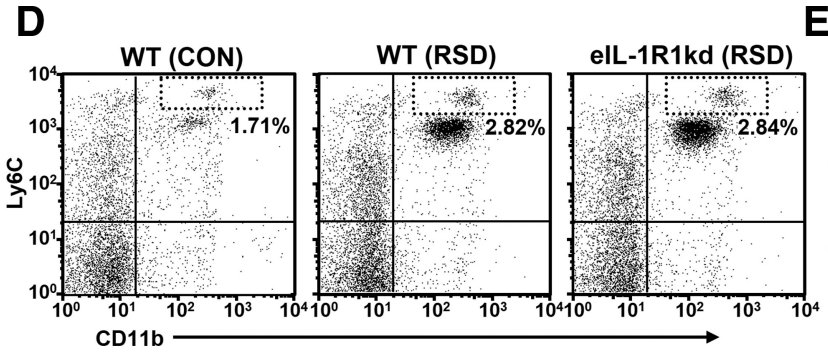

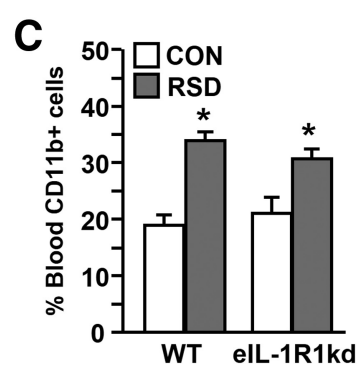

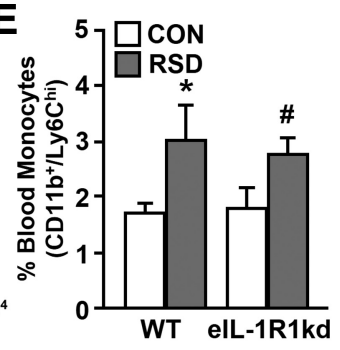

Figure 3. RSD increased spleen weight, circulating myeloid cells, and enhanced the inflammatory potential of CD11b ${ }^{+}$splenocytes in elL-1R1kd mice. WT and elL-1R1kd FVB mice were subjected to RSD or left undisturbed as CON mice. $A$, Average spleen weight. $\boldsymbol{B}$, Plasma corticosterone levels. $\boldsymbol{C}$, Percentage of $\mathrm{CD} 11 \mathrm{~b}^{+}$cells in the blood. $\boldsymbol{D}$, Representative flow bivariate dot plots of CD11b/Ly6C labeling. $E$, Average percentage of CD11b ${ }^{+} /$Ly6 $\mathrm{C}^{\text {hi }}$ monocytes are shown. Bars represent average $\pm S E M .{ }^{*} p<0.05$, significantly different from CON. ${ }^{\#} p<0.10$, different from CON.

Table 1. RSD increased CD11b ${ }^{+}$splenocyte proinflammatory gene expression after LPS stimulation

\begin{tabular}{|c|c|c|c|c|c|}
\hline \multirow[b]{2}{*}{ Gene } & \multirow[b]{2}{*}{ LPS } & \multicolumn{2}{|l|}{ WT } & \multicolumn{2}{|l|}{ elL-1R1kd } \\
\hline & & $\mathrm{CON}$ & RSD & $\mathrm{CON}$ & RSD \\
\hline \multicolumn{6}{|l|}{$I L-1 \beta$} \\
\hline & - & $1.05 \pm 0.16$ & $4.30 \pm 1.19^{\#}$ & $0.85 \pm 0.17$ & $7.06 \pm 2.49^{\#}$ \\
\hline & + & $4.83 \pm 0.89^{*}$ & $24.16 \pm 6.70^{*, \neq}$ & $4.60 \pm 1.13^{*}$ & $25.72 \pm 6.19^{*, \neq}$ \\
\hline \multicolumn{6}{|l|}{ TNF- $\alpha$} \\
\hline & - & $1.04 \pm 0.04$ & $4.89 \pm 1.49^{\#}$ & $0.80 \pm 0.17$ & $5.91 \pm 1.93^{\#}$ \\
\hline & + & $8.81 \pm 0.65^{*}$ & $45.78 \pm 10.45^{*, \neq}$ & $8.53 \pm 2.84^{*}$ & $47.82 \pm 14.40^{*, \neq}$ \\
\hline \multicolumn{2}{|l|}{ IL-6 } & $1.00 \pm 0.05$ & $4.86 \pm 1.09^{\#}$ & $0.99 \pm 0.02$ & $2.53 \pm 0.52^{\#}$ \\
\hline & + & $6.42 \pm 1.21^{*}$ & $43.11 \pm 13.48^{*, \neq}$ & $8.18 \pm 1.88^{*}$ & $26.24 \pm 6.10^{*, \neq}$ \\
\hline
\end{tabular}

WT and ell-1R1KD FVB mice were subjected to RSD or left undisturbed as CON mice. Enriched CD11 ${ }^{+}$splenocytes were stimulated with saline ( - ) or LPS ( + ). Relative mRNA expression of IL-1 $\beta$, TNF- $\alpha$, and IL-6 in LPS-stimulated $\mathrm{CD}_{11 \mathrm{~b}}{ }^{+}$splenocytes is shown. Values represent average \pm SEM. ${ }^{*} p<0.05$, significantly different from WT$\operatorname{CON}(-) ;{ }^{*} p<0.10$, different from WT-CON $(-) ;{ }^{*} p<0.05$, significantly different from WT-CON $(+)$ and WT-RSD(-).

et al., 2011). Therefore, microglia morphology was examined in WT or eIL-1R1kd mice subjected to RSD or left undisturbed as controls. Fig. 5A shows representative images of Iba-1 immunoreactivity in the AMYG of WT-CON, WT-RSD, and eIL-1R1kdRSD mice. As expected, microglia displayed de-ramified morphology in WT mice with increased Iba-1 proportional area after RSD. Microglia in eIL-1R1kd mice had similar de-ramified morphology after RSD. Indeed, Iba-1 proportional area was increased in the AMYG $\left(F_{(1,14)}=19.04, p<0.001\right.$; Fig. $\left.5 B\right)$, PFC $\left(F_{(1,16)}=12.94, p<0.003\right.$; Fig. $\left.5 C\right), \operatorname{PVN}\left(F_{(1,14)}=17.51, p<\right.$ 0.002; Fig. $5 D)$, and the HPC-DG $\left(F_{(1,16)}=9.53, p<0.009\right.$; Fig. $5 E$ ) of both WT and eIL1R1kd mice. It is also worthwhile to note that microglia activation was modestly attenuated in the PFC and PVN of eIL-1R1kd mice (stress $\times$ genotype interaction; $p<0.05$, for each). Moreover, RSD did not increase Iba-1 proportional area in the CA1 or CA2 of the HPC. These results demonstrate that RSD-induced macrophage trafficking to the brain, and brain region-specific microglia activation occurred independent of endothelial cell-specific expression of IL-1R1.
eIL-1R1kd mice have attenuated inflammatory gene expression in enriched brain CD11b ${ }^{+}$cells after RSD To characterize the activation state of deramified microglia and brain macrophages after RSD, we next determined the expression of several inflammatoryrelated genes in enriched brain $\mathrm{CD}_{11 \mathrm{~b}}{ }^{+}$ cells from WT and eIL-1R1kd mice. Table 2 shows RSD markedly altered gene expression of inflammatory-related genes in brain $\mathrm{CD}_{11 \mathrm{~b}}{ }^{+}$cells, and these changes were dependent on IL-1R1 expression on endothelial cells. For instance, IL- $1 \beta$, TNF- $\alpha$, CCL2, and CD14 (main effect of stress, $p<0.05$, for each) mRNA levels were increased in WT mice after RSD. However, in eIL-1R1kd mice, mRNA levels of IL- $1 \beta$, TNF- $\alpha$, IL- 6 , and CCL 2 were markedly reduced compared with WT mice (stress $\times$ genotype interaction, $p<$ 0.08, for each). Moreover, $\mathrm{CX}_{3} \mathrm{CR} 1 \mathrm{ex}-$ pression was decreased after RSD in both WT and eIL-1R1kd mice $\left(F_{(1,32)}=10.53\right.$, $p<0.03)$. These findings show that RSDinduced proinflammatory gene expression in brain $\mathrm{CD}_{1} \mathrm{~b}^{+}$cells was attenuated in eIL-1R1kd mice.

\section{Endothelial knockdown of IL-1R1 prevented RSD-induced anxiety-like behavior}

Previous reports indicate that RSD-induced neuroinflammation and macrophage recruitment to the brain contributes to development of anxiety-like behavior (Wohleb et al., 2013). Representative motion plots of open-field activity in Figure $6 \mathrm{~A}$ show that WT mice subjected to RSD displayed thigmotaxis, whereas eIL$1 \mathrm{R} 1 \mathrm{kd}$ mice readily explore the open-field after RSD. Indeed, RSD increased anxiety-like behavior in WT mice with increased latency to enter the open field (Fig. 6B) and decreased time spent in the center (Fig. 6C). Furthermore, RSD-induced anxiety-like behavior was attenuated in eIL-1R1kd mice (stress $\times$ genotype interaction, $p<0.04$, for each). Anxiety-like behavior in the light/dark preference test was also dependent on endothelial cellspecific IL-1R1 expression. For instance, WT mice decreased time to enter the dark zone $\left(F_{(1,28)}=4.77, p<0.04\right)$ and increased time spent in the dark zone $\left(F_{(1,28)}=6.55, p<0.02\right)$, but these responses were not evident in eIL-1R1kd mice after RSD (stress $\times$ genotype interaction, $p<0.07$, for each). These data demonstrate that reduced IL-1R1 expression on endothelial cells blocked development of anxiety-like behavior after RSD.

\section{Discussion}

Increased expression of IL- $1 \beta$ in the brain after stress exposure contributes to neurobiological responses that underlie development of mood disturbances (Koo and Duman, 2008; Goshen and Yirmiya, 2009). In support of this notion, previous findings in RSD show that microglia activation and recruitment of peripheral macrophages to the brain enhanced IL- $1 \beta$ mRNA levels, which corresponded with development of anxiety (Wohleb et al., 2011, 2012, 2013). In addition, IL-1R ${ }^{\mathrm{KO}}$ mice do not exhibit microglia activation and fail to develop anxiety after RSD (Wohleb et al., 2011). Here we extend these findings to show that RSD does not promote release of myeloid cells into circulation, which diminished macrophage trafficking to the brain of IL-1R 1 KO 
mice. Moreover, lack of macrophage trafficking to the brain of IL-1R $1{ }^{\mathrm{KO}}$ mice corresponded with reduced Iba- 1 immunoreactivity after RSD. Subsequent studies using eIL-1R1kd mice revealed that recruitment of primed macrophages in the brain and altered microglia morphology were maintained, but proinflammatory gene expression in brain CD11b ${ }^{+}$ cells and anxiety behavior was attenuated. Figure 7 summarizes the effects of IL$1 \mathrm{R} 1^{\mathrm{KO}}$ and eIL-1R1kd on neuroimmune and behavioral responses after RSD. These findings indicate that IL-1 signaling is an integral mediator of peripheral and central neuroimmune responses elicited by RSD.

One important finding of this study was that IL-1R1 ${ }^{\mathrm{KO}}$ prevented the stressinduced release of monocytes into circulation and subsequent trafficking to the brain. For instance, RSD increased blood monocytes in circulation and in the brain of WT mice but not in IL-1R $1{ }^{\mathrm{KO}}$ mice. Moreover, studies using $\mathrm{GFP}^{+} \mathrm{BM}$ chimera mice showed that, although there was robust trafficking into the brain parenchyma of WT recipient mice, macrophage infiltration was not evident in the brain of IL-1R1 ${ }^{\mathrm{KO}}$ recipient mice. Diminished macrophage trafficking in the brain of IL-1R1 ${ }^{\mathrm{KO}}$ recipient mice was associated with limited alterations in microglia morphology, indicating that neuroinflammatory responses were reduced. These findings are consistent with previous reports that indicate that IL- $1 \mathrm{R} 1^{\mathrm{KO}}$ mice have increased IL-1 levels in circulation after RSD but did not have increased myeloid cells in the BM, blood, or spleen. Despite elevated levels of GCs, splenocytes from IL-1R $1^{\mathrm{KO}}$ mice did not have GC insensitivity after RSD (Engler et al., 2008). These findings indicate that RSD-induced priming and release of myeloid cells relies on IL- 1 signaling. In IL-1R1 ${ }^{\mathrm{KO}}$ mice, it is unclear whether central or peripheral IL-1 signaling is required for immune and behavioral alterations caused by RSD because these mice have systemic ablation of IL-1R1. Moreover, peripheral and central IL-1 can initiate neuroendocrine responses that promote activation and redistribution of peripheral myeloid cells (Bierhaus et al., 2003; Sternberg, 2006; Sorrells et al., 2009; Dhabhar et al., 2012). This is pertinent because IL-1 signaling can cause sympathetic nervous system activation (Black, 2002; Murakami et al., 2002), which is integral in RSD-induced priming and redistribution of myeloid cells (Hanke et al., 2012; Powell et al., 2013). In addition, recent work indicates
A
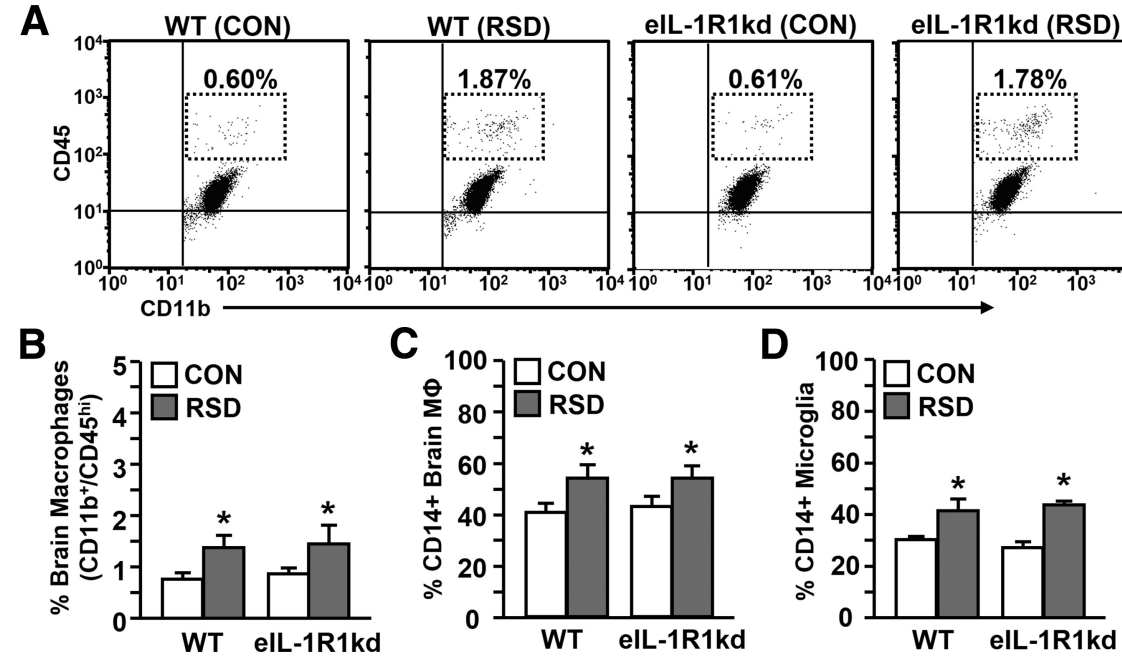

Figure 4. RSD promoted recruitment of peripheral macrophages and increased activation markers on brain CD11 ${ }^{+}{ }^{+}$cells in WT and elL-1R1kd mice. WT and elL-1R1kd FVB mice were subjected to RSD or left undisturbed as CON. Brains were collected $14 \mathrm{~h}$ after the final cycle and brain CD11b ${ }^{+}$cells (microglia/macrophages) were isolated. $A$, Representative flow bivariate dot plots of CD11b/CD45 labeling. $\boldsymbol{B}$, Average percentage of $\mathrm{CD} 11 \mathrm{~b}^{+} / \mathrm{CD} 45^{\text {hi }}$ brain macrophages. $\boldsymbol{C}$, Average proportion of CD14 ${ }^{+}$macrophages. $\boldsymbol{D}$, Average proportion of $\mathrm{CD} 14^{+}$microglia in the brain. Bars represent average \pm SEM. ${ }^{*} p<0.05$, significantly different from CON.

\section{A}
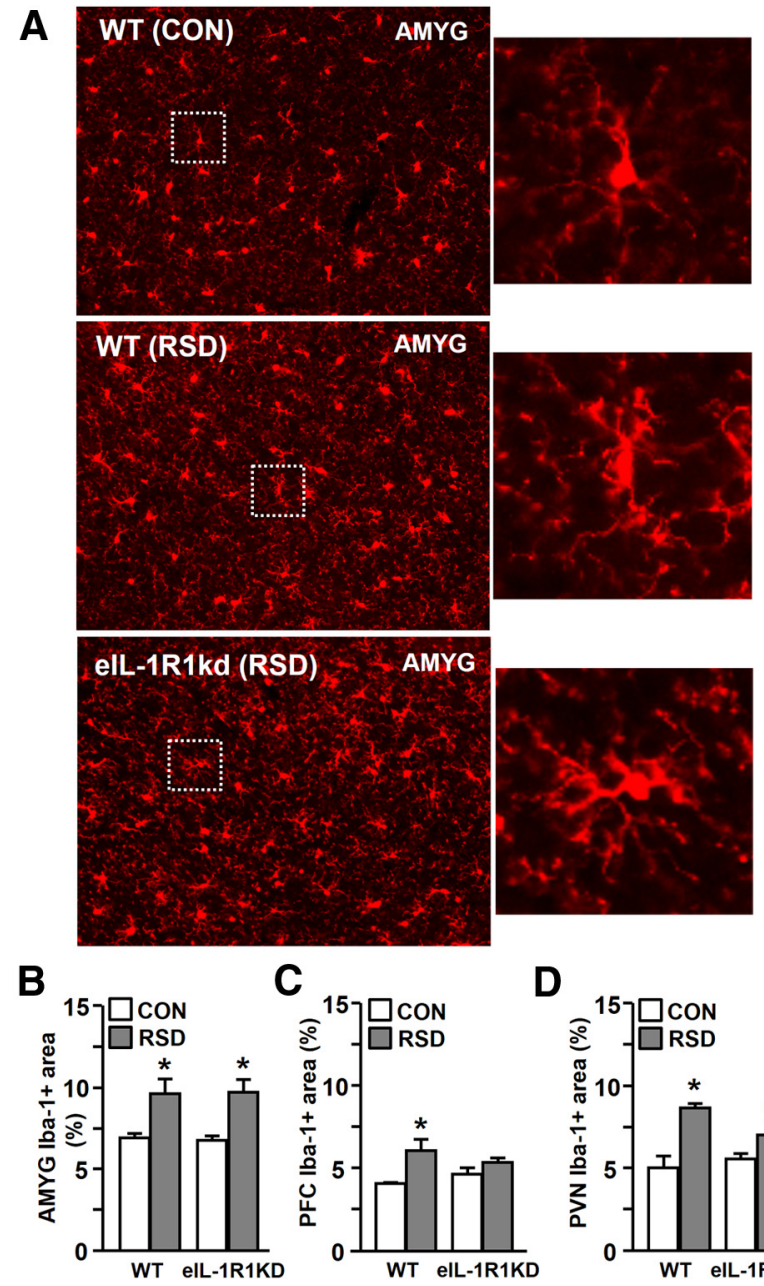

C
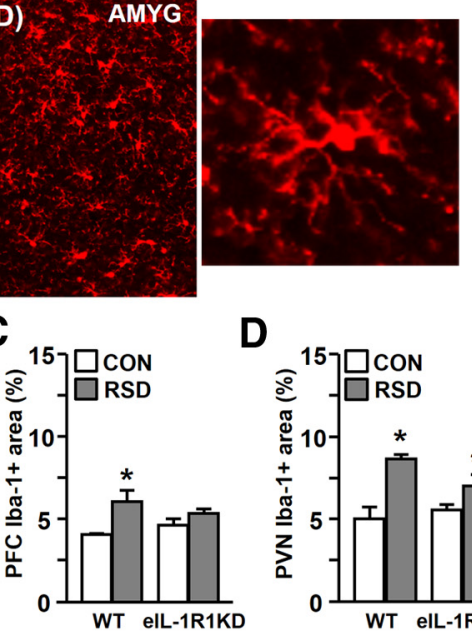

D

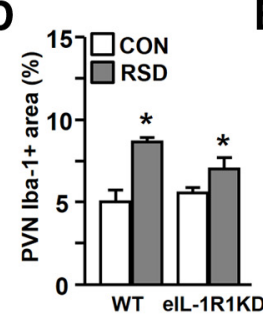

E

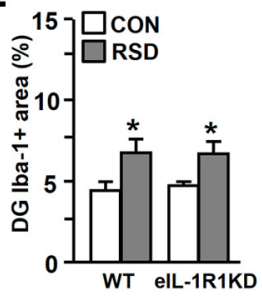

Figure 5. RSD enhanced lba-1 proportional area in the PFC, PVN, AMYG, and HPC of elL-1R1kd mice. WT and ell-1R1kd FVB mice were subjected to RSD or left undisturbed as CON. Brains were collected $14 \mathrm{~h}$ after RSD for histology. $\boldsymbol{A}$, Representative images of Iba-1 labeling in the AMYG of WT-CON, WT-RSD, and elL-1R1kd-RSD mice are shown. Average lba-1 proportional area in the AMYG $(\boldsymbol{B}), \operatorname{PFC}(\boldsymbol{C}), \operatorname{PVN}(\boldsymbol{D})$, and HPC-DG $(\boldsymbol{E})$ are shown. Enlarged image of $\mathrm{lba}-1^{+}$microglia indicated by dashed outline . Bars represent average $\pm S E M .{ }^{*} p<0.05$, significantly different from CON. 
Table 2. elL-1R1KD attenuated RSD-induced inflammatory gene expression in enriched brain $\mathrm{CD} 11 \mathrm{~b}{ }^{+}$cells

\begin{tabular}{llclll}
\hline \multirow{2}{*}{ Gene } & WT & CON & RSD & & elL-1R1kd \\
\cline { 2 - 3 } \cline { 5 - 6 } IL-1 $\beta$ & $1.02 \pm 0.09$ & $4.37 \pm 1.08^{*, \pm}$ & & $1.28 \pm 0.36$ & $2.19 \pm 0.37^{*}$ \\
TNF- $\alpha$ & $1.03 \pm 0.11$ & $3.19 \pm 1.04^{*}$ & & $1.24 \pm 0.37$ & $1.21 \pm 0.32$ \\
IL-6 & $1.19 \pm 0.31$ & $4.01 \pm 1.88^{*, \pm}$ & & $1.86 \pm 0.64$ & $1.27 \pm 0.22$ \\
CCL2 & $1.03 \pm 0.09$ & $11.30 \pm 4.93^{*, \pm}$ & & $1.57 \pm 0.40$ & $2.59 \pm 0.74$ \\
CD14 & $1.03 \pm 0.11$ & $4.18 \pm 1.80^{*}$ & & $1.10 \pm 0.31$ & $2.08 \pm 0.47$ \\
CX $X_{3}$ CR1 & $1.00 \pm 0.03$ & $0.74 \pm 0.10^{\#}$ & & $1.09 \pm 0.21$ & $0.72 \pm 0.11^{\#}$ \\
\hline
\end{tabular}

WT and elL-1R1kd FVB mice were subjected to RSD or left undisturbed as CON mice. Enriched brain CD11b ${ }^{+}$cells were collected, and relative mRNA expression of IL-1 $\beta$, TNF- $\alpha, \mathrm{IL}-6, \mathrm{CCL} 2, \mathrm{CD} 14$, and $\mathrm{CX}{ }_{3} \mathrm{CR} 1$ is shown. Values represent average \pm SEM. ${ }^{*} p<0.05$, significantly different from WT-CON; ${ }^{*} p<0.10$, different from WT-CON; ${ }^{\ddagger} p<0.05$, significantly different from ell-1R $1 \mathrm{kd}-\mathrm{CON}$
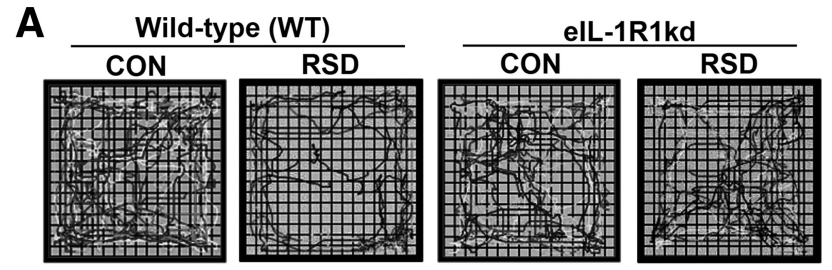

B
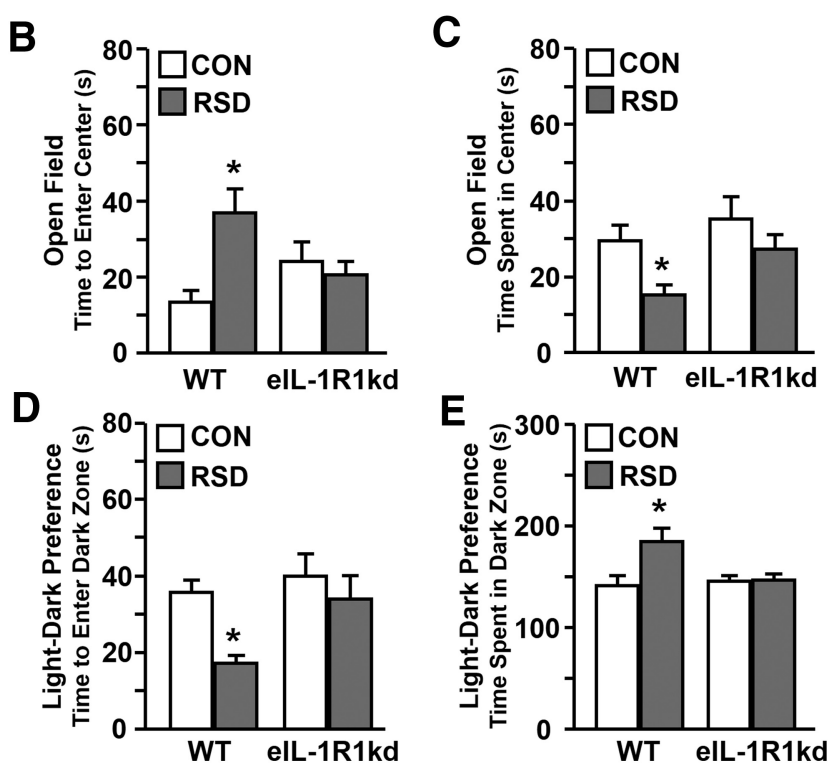

Figure 6. Endothelial knockdown of IL-1R1 prevented RSD-induced anxiety-like behavior. WT and elL-1R1kd FVB mice were subjected to RSD or left undisturbed as CON. Anxiety-like behavior was tested $14 \mathrm{~h}$ after the final cycle of RSD. $\boldsymbol{A}$, Representative motion plots of each experimental group in the open field. $\boldsymbol{B}$, Average time to enter the open-field center. $\boldsymbol{C}$, Average time spent in the open-field center. $\boldsymbol{D}$, Average time to enter the dark zone. $\boldsymbol{E}$, Average time spent in the dark zone of the light/dark preference paradigm are shown. Bars represent average \pm SEM. ${ }^{*} p<0.05$, significantly different from CON.

that RSD-induced macrophage trafficking in the brain is necessary for development of anxiety-like behavior (Wohleb et al., 2013). Thus, limited microglia activation and decreased trafficking of primed myeloid cells in the brain of IL-1R $1^{\mathrm{KO}}$ mice likely underlie reduced anxiety responses after RSD (Wohleb et al., 2011). These findings indicate that IL-1R1 signaling is required for RSD-induced myeloid cell priming, and, in the absence of IL-1R1, neuroinflammatory and anxiety responses are abolished.

Stress-induced elevations of IL-1 can also direct neuroimmune responses through propagation of signals via endothelial cells of the blood-brain barrier (BBB). For instance, endothelial cells of the BBB express key cytokine receptors (i.e., IL-1R1, TNF receptor), and binding of these receptors leads to transport or secretion of additional proinflammatory cytokines and secondary mediators (i.e., prostaglandins; Ericsson et al., 1995; Quan and Banks, 2007). Thus, transgenic eIL-1R1kd mice were used to further elucidate neuroimmune interactions that contribute to RSD-induced macrophage trafficking and anxiety. In contrast to $\mathrm{IL}-1 \mathrm{R} 1^{\mathrm{KO}}$ mice, RSD caused splenomegaly along with increased circulating myeloid cells and monocytes in WT and eIL$1 \mathrm{R} 1 \mathrm{kd}$ mice. Furthermore, RSD-induced priming of peripheral myeloid cells was similar in WT and eIL-1R1kd mice. For instance, LPS stimulation exaggerated IL- $1 \beta$, TNF- $\alpha$, and IL- 6 gene expression in $\mathrm{CD} 11 \mathrm{~b}^{+}$splenocytes from RSD mice compared with CON mice. The presence of primed monocytes in the periphery is consistent with our previous findings (Stark et al., 2001; Avitsur et al., 2005; Bailey et al., 2009) and reflects clinical reports that psychological stress promoted inflammatory gene transcription in peripheral mononuclear cells (Miller et al., 2008; Cole et al., 2010). The enhanced inflammatory capacity of peripheral mononuclear cells after stress is related to impaired nuclear translocation of the GC receptor, resulting in enhanced signaling through the canonical inflammatory nuclear factor $-\kappa \mathrm{B}$ pathway (Quan et al., 2003; Pace et al., 2007). These alterations are pertinent because enhanced mononuclear cell activation is associated with inflammatory-related complications and may underlie prolonged mood disturbances (Beumer et al., 2012; Silverman and Sternberg, 2012). In consideration of these possibilities, our present findings indicate that RSD-induced priming and redistribution of myeloid cells occur independently of endothelial cell IL-1R1 expression.

Similar to previous reports, RSD-induced priming and redistribution of peripheral monocytes were associated with significant accumulation of brain macrophages in WT and eIL-1R1kd mice. These findings are distinct from other neuroinflammatory and neurological disease models that show that endothelial cell IL-1R1 expression mediates myeloid cell recruitment and pathogenesis (Ching et al., 2007; Li et al., 2011). Contrary to these reports, eIL-1R1kd mice did not block recruitment of primed monocytes to the brain after RSD. Thus, other cell types in the brain may contribute to monocyte recruitment after RSD. For instance, stress may promote astrocyte activation, leading to increased production of chemokines (i.e., CCL2) that attract monocytes to the brain (Madrigal et al., 2010). Moreover, IL-1independent pathways may promote microglia activation that underlies RSD-induced macrophage trafficking. For instance, increased GC release and localized norepinephrine secretion in the brain can prime microglia-mediated inflammatory responses (Frank et al., 2010; Porterfield et al., 2012). In support of this idea, previous studies in RSD show that brain region-specific microglia activation and macrophage trafficking was blocked by pretreatment with $\beta$-adrenergic receptor antagonism (Wohleb et al., 2011). In addition, morphological analyses of microglia by Iba- 1 immunoreactivity showed that eIL-1R1kd mice had de-ramified microglia in the PVN, AMYG, and HPC after RSD. Notably, RSD did not alter microglia morphology in the PFC of eIL-1R1kd mice, which indicates that specific brain regions have dynamic responses to stress-induced neuroimmune activation (Cerqueira et al., 2007; Hinwood et al., 2012). These results indicate that RSD caused central and peripheral neuroimmune activation independent of endothelial IL-1R1 because eIL-1R1kd does not prevent RSD-induced macrophage trafficking in the brain or altered microglia morphology.

A key finding in this study was that IL-1R1 on brain endothelial cells plays an integral role in propagation of neuroinflammatory signaling in response to stress. For example, brain CD11b ${ }^{+}$ 


\section{A wild-type (RSD)}

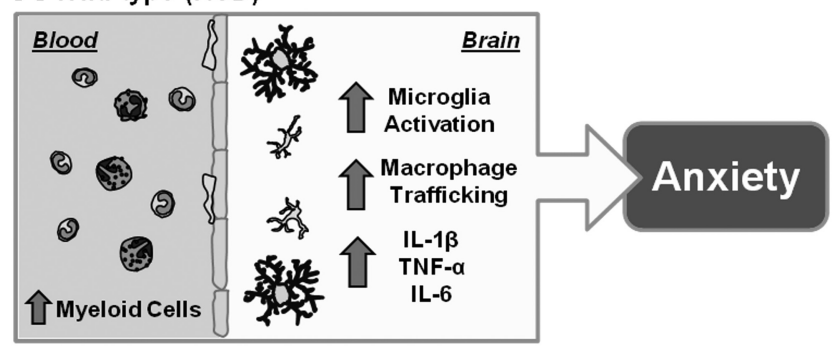

\section{B IL-1R1 ${ }^{\mathrm{KO}}$ (RSD)}

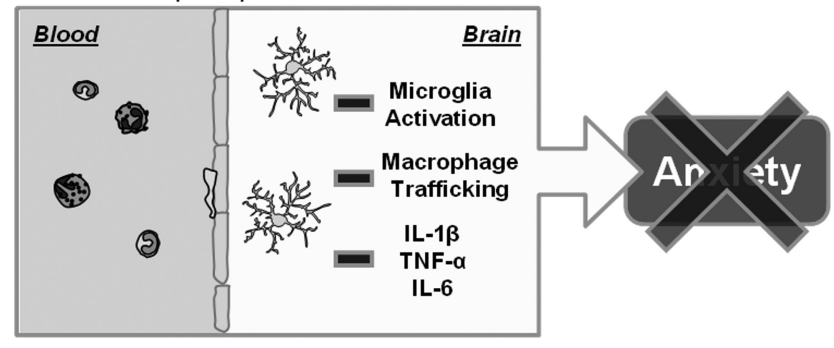

\section{C elL-1R1KD (RSD)}

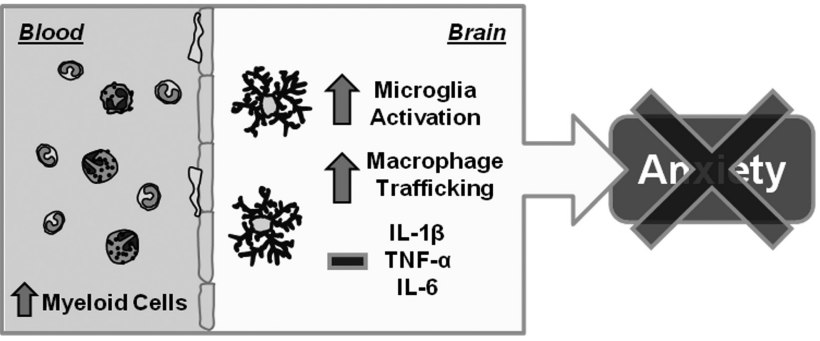

Figure 7. IL-1R1 expression mediates central and peripheral immune responses that are critical in development of RSD-induced anxiety-like behavior. $\boldsymbol{A}$, WT mice subjected to RSD have increased primed myeloid cells in circulation, leading to robust macrophage trafficking in the brain that corresponded with microglia activation. These brain CD11b ${ }^{+}$cells have increased proinflammatory cytokine production (IL- $1 \beta$, TNF- $\alpha, \mathrm{IL}-6)$ that promoted development of anxiety-like behavior after RSD. $\boldsymbol{B}, I L-1 R 1^{\mathrm{K} 0}$ mice subjected to RSD do not develop primed myeloid cells in circulation, leading to reduced macrophage trafficking in the brain and limited microglia activation. These mice fail to development anxiety-like behavior after RSD. C, elL1 R1kd mice subjected to RSD have increased primed myeloid cells in circulation, leading to robust macrophage trafficking in the brain that corresponded with microglia activation. Limited IL-1 signaling at the vascular interface attenuated proinflammatory cytokine production (IL$1 \beta$, TNF- $\alpha$, IL-6), preventing development of anxiety-like behavior after RSD.

cells isolated from eIL-1R1kd mice had attenuated mRNA levels of IL- $1 \beta$, IL- 6 , and TNF- $\alpha$ compared with WT mice. It is important to point out that RSD-induced IL- $1 \beta$ expression was attenuated but not ablated in brain CD11b ${ }^{+}$cells from eIL-1R1kd mice. Moreover, eIL-1R1kd and WT mice showed comparable morphological changes in microglia through Iba-1 immunohistology. These data are inconsistent with previous studies that showed that proinflammatory cytokine levels corresponded with increased Iba-1 proportional area after RSD (Wohleb et al., 2011, 2012, 2013). These data indicate that Iba-1 proportional area may not represent the inflammatory potential of microglia, and several approaches, including immunohistology, flow cytometry, and mRNA analyses, should be used to define their activation state. Indeed, recent reports indicate that analyses of microglia morphology alone may not accurately reflect their function (Beynon and Walker, 2012; Boche et al., 2013). Collectively, these findings suggest that RSD alters microglia phenotype, but endothelial expression of IL-1R1 is required to amplify proinflammatory cytokine production in brain $\mathrm{CD} 11 \mathrm{~b}^{+}$cells. Furthermore, we show novel data that attenuation of RSD-induced neuroinflammation prevented development of anxiety-like behavior in eIL-1R1kd mice. These findings support our previous studies that demonstrate that neuroinflammation and macrophage trafficking in the brain contribute to RSD-induced anxiety (Wohleb et al., 2011, 2013). It is important to note that eIL-1R1kd mice maintained similar stress responses as WT mice, but disrupted IL-1 signaling at the vascular interface prevented the development of anxiety. These results indicate that neuroinflammatory signals generated by resident microglia and trafficking macrophages converge on vascular endothelial cells, which potentiates these signals leading to development of anxiety. Therefore, dynamic interactions between microglia, perivascular macrophages, and vascular endothelial cells are necessary to promote RSD-induced anxiety.

In summary, this study provides evidence that IL-1R1 signaling mediates peripheral and central immune alterations that underlie development of stress-induced anxiety. These findings indicate that development of stress-induced anxiety was dependent on microglia activation and recruitment of primed monocytes to the brain. Furthermore, knockdown of IL-1R1 in endothelial cells attenuated potentiation of neuroinflammatory signals, which prevented anxiety-like behavior after stress. These results suggest that the IL-1 signaling at the vascular interface is a potential target to alleviate stress-associated mood disturbances.

\section{References}

Allan SM, Tyrrell PJ, Rothwell NJ (2005) Interleukin-1 and neuronal injury. Nat Rev Immunol 5:629-640. CrossRef Medline

Avitsur R, Kavelaars A, Heijnen C, Sheridan JF (2005) Social stress and the regulation of tumor necrosis factor-alpha secretion. Brain Behav Immun 19:311-317. CrossRef Medline

Bailey MT, Kinsey SG, Padgett DA, Sheridan JF, Leblebicioglu B (2009) Social stress enhances IL-1beta and TNF-alpha production by Porphyromonas gingivalis lipopolysaccharide-stimulated $\mathrm{CD} 11 \mathrm{~b}+$ cells. Physiol Behav 98:351-358. CrossRef Medline

Beumer W, Gibney SM, Drexhage RC, Pont-Lezica L, Doorduin J, Klein HC, Steiner J, Connor TJ, Harkin A, Versnel MA, Drexhage HA (2012) The immune theory of psychiatric diseases: a key role for activated microglia and circulating monocytes. J Leukoc Biol 92:959-975. CrossRef Medline

Beynon SB, Walker FR (2012) Microglial activation in the injured and healthy brain: what are we really talking about? Practical and theoretical issues associated with the measurement of changes in microglial morphology. Neuroscience 225:162-171. CrossRef Medline

Bierhaus A, Wolf J, Andrassy M, Rohleder N, Humpert PM, Petrov D, Ferst R, von Eynatten M, Wendt T, Rudofsky G, Joswig M, Morcos M, Schwaninger M, McEwen B, Kirschbaum C, Nawroth PP (2003) A mechanism converting psychosocial stress into mononuclear cell activation. Proc Natl Acad Sci U S A 100:1920-1925. CrossRef Medline

Black PH (2002) Stress and the inflammatory response: a review of neurogenic inflammation. Brain Behav Immun 16:622-653. CrossRef Medline

Blandino P Jr, Barnum CJ, Solomon LG, Larish Y, Lankow BS, Deak T (2009) Gene expression changes in the hypothalamus provide evidence for regionally-selective changes in IL-1 and microglial markers after acute stress. Brain Behav Immun 23:958-968. CrossRef Medline

Boche D, Perry VH, Nicoll JA (2013) Review: activation patterns of microglia and their identification in the human brain. Neuropathol Appl Neurobiol 39:3-18. CrossRef Medline

Cerqueira JJ, Mailliet F, Almeida OF, Jay TM, Sousa N (2007) The prefrontal cortex as a key target of the maladaptive response to stress. J Neurosci 27:2781-2787. CrossRef Medline

Ching S, Zhang H, Belevych N, He L, Lai W, Pu XA, Jaeger LB, Chen Q, Quan N (2007) Endothelial-specific knockdown of interleukin-1 (IL-1) type 1 receptor differentially alters CNS responses to IL-1 depending on its route of administration. J Neurosci 27:10476-10486. CrossRef Medline

Christoffel DJ, Golden SA, Dumitriu D, Robison AJ, Janssen WG, Ahn HF, Krishnan V, Reyes CM, Han MH, Ables JL, Eisch AJ, Dietz DM, Ferguson D, Neve RL, Greengard P, Kim Y, Morrison JH, Russo SJ (2011) I $\mathrm{B}$ 
kinase regulates social defeat stress-induced synaptic and behavioral plasticity. J Neurosci 31:314-321. CrossRef Medline

Cole SW, Arevalo JM, Takahashi R, Sloan EK, Lutgendorf SK, Sood AK, Sheridan JF, Seeman TE (2010) Computational identification of genesocial environment interaction at the human IL6 locus. Proc Natl Acad Sci U S A 107:5681-5686. CrossRef Medline

Dhabhar FS, Malarkey WB, Neri E, McEwen BS (2012) Stress-induced redistribution of immune cells-from barracks to boulevards to battlefields: a tale of three hormones-Curt Richter Award winner. Psychoneuroendocrinology 37:1345-1368. CrossRef Medline

Donnelly DJ, Gensel JC, Ankeny DP, van Rooijen N, Popovich PG (2009) An efficient and reproducible method for quantifying macrophages in different experimental models of central nervous system pathology. J Neurosci Methods 181:36-44. CrossRef Medline

Engler H, Engler A, Bailey MT, Sheridan JF (2005) Tissue-specific alterations in the glucocorticoid sensitivity of immune cells following repeated social defeat in mice. J Neuroimmunol 163:110-119. CrossRef Medline

Engler H, Bailey MT, Engler A, Stiner-Jones LM, Quan N, Sheridan JF (2008) Interleukin-1 receptor type 1-deficient mice fail to develop social stressassociated glucocorticoid resistance in the spleen. Psychoneuroendocrinology 33:108-117. CrossRef Medline

Ericsson A, Liu C, Hart RP, Sawchenko PE (1995) Type 1 interleukin-1 receptor in the rat brain: distribution, regulation, and relationship to sites of IL-1-induced cellular activation. J Comp Neurol 361:681-698. CrossRef Medline

Eyre H, Baune BT (2012) Neuroplastic changes in depression: a role for the immune system. Psychoneuroendocrinology 37:1397-1416. CrossRef Medline

Frank MG, Miguel ZD, Watkins LR, Maier SF (2010) Prior exposure to glucocorticoids sensitizes the neuroinflammatory and peripheral inflammatory responses to E. coli lipopolysaccharide. Brain Behav Immun 24: 19-30. CrossRef Medline

Goshen I, Yirmiya R (2009) Interleukin-1 (IL-1): a central regulator of stress responses. Front Neuroendocrinol 30:30-45. CrossRef Medline

Hanke ML, Powell ND, Stiner LM, Bailey MT, Sheridan JF (2012) $\beta$-adrenergic blockade decreases the immunomodulatory effects of social disruption stress. Brain Behav Immun 26:1150-1159. CrossRef Medline

Hinwood M, Morandini J, Day TA, Walker FR (2012) Evidence that microglia mediate the neurobiological effects of chronic psychological stress on the medial prefrontal cortex. Cereb Cortex 22:1442-1454. CrossRef Medline

Johnson JD, Campisi J, Sharkey CM, Kennedy SL, Nickerson M, Greenwood BN, Fleshner M (2005) Catecholamines mediate stress-induced increases in peripheral and central inflammatory cytokines. Neuroscience 135:1295-1307. CrossRef Medline

Koo JW, Duman RS (2008) IL-1beta is an essential mediator of the antineurogenic and anhedonic effects of stress. Proc Natl Acad Sci U S A 105:751756. CrossRef Medline

Koo JW, Duman RS (2009) Evidence for IL-1 receptor blockade as a therapeutic strategy for the treatment of depression. Curr Opin Investig Drugs 10:664-671. Medline

Koo JW, Russo SJ, Ferguson D, Nestler EJ, Duman RS (2010) Nuclear factor-kappaB is a critical mediator of stress-impaired neurogenesis and depressive behavior. Proc Natl Acad Sci U S A 107:2669-2674. CrossRef Medline

Li Q, Powell N, Zhang H, Belevych N, Ching S, Chen Q, Sheridan J, Whitacre C, Quan N (2011) Endothelial IL-1R1 is a critical mediator of EAE pathogenesis. Brain Behav Immun 25:160-167. CrossRef Medline

Madrigal JL, Garcia-Bueno B, Hinojosa AE, Polak P, Feinstein DL, Leza JC (2010) Regulation of MCP-1 production in brain by stress and noradrenaline-modulating drugs. J Neurochem 113:543-551. CrossRef Medline

Miller GE, Chen E, Sze J, Marin T, Arevalo JM, Doll R, Ma R, Cole SW (2008) A functional genomic fingerprint of chronic stress in humans: blunted glucocorticoid and increased NF-kappaB signaling. Biol Psychiatry 64: 266-272. CrossRef Medline
Murakami Y, Okada S, Yokotani K (2002) Brain inducible nitric oxide synthase is involved in interleukin-1beta-induced activation of the central sympathetic outflow in rats. Eur J Pharmacol 455:73-78. CrossRef Medline

Ohtsuki S, Kamiya N, Hori S, Terasaki T (2005) Vascular endotheliumselective gene induction by Tie2 promoter/enhancer in the brain and retina of a transgenic rat. Pharm Res 22:852-857. CrossRef Medline

Pace TW, Hu F, Miller AH (2007) Cytokine-effects on glucocorticoid receptor function: relevance to glucocorticoid resistance and the pathophysiology and treatment of major depression. Brain Behav Immun 21:9-19. CrossRef Medline

Paxinos G, Franklin K (2008) The mouse brain in stereotaxic coordinates. Ed 3. San Francisco: Academic Press.

Porterfield VM, Gabella KM, Simmons MA, Johnson JD (2012) Repeated stressor exposure regionally enhances beta-adrenergic receptor-mediated brain IL-1beta production. Brain Behav Immun 26:1249-1255. CrossRef Medline

Powell ND, Sloan EK, Bailey MT, Arevalo JM, Miller GE, Chen E, Kobor MS, Reader BF, Sheridan JF, Cole SW (2013) Social stress up-regulates inflammatory gene expression in the leukocyte transcriptome via betaadrenergic induction of myelopoiesis. Proc Natl Acad Sci U S A 110: 16574-16579. CrossRef Medline

Quan N, Banks WA (2007) Brain-immune communication pathways. Brain Behav Immun 21:727-735. CrossRef Medline

Quan N, Avitsur R, Stark JL, He L, Lai W, Dhabhar F, Sheridan JF (2003) Molecular mechanisms of glucocorticoid resistance in splenocytes of socially stressed male mice. J Neuroimmunol 137:51-58. CrossRef Medline

Serrats J, Schiltz JC, García-Bueno B, van Rooijen N, Reyes TM, Sawchenko PE (2010) Dual roles for perivascular macrophages in immune-to-brain signaling. Neuron 65:94-106. CrossRef Medline

Silverman MN, Sternberg EM (2012) Glucocorticoid regulation of inflammation and its functional correlates: from HPA axis to glucocorticoid receptor dysfunction. Ann NY Acad Sci 1261:55-63. CrossRef Medline

Sorrells SF, Caso JR, Munhoz CD, Sapolsky RM (2009) The stressed CNS: when glucocorticoids aggravate inflammation. Neuron 64:33-39. CrossRef Medline

Stark JL, Avitsur R, Padgett DA, Campbell KA, Beck FM, Sheridan JF (2001) Social stress induces glucocorticoid resistance in macrophages. Am J Physiol Regul Integr Comp Physiol 280:R1799-R1805. Medline

Sternberg EM (2006) Neural regulation of innate immunity: a coordinated nonspecific host response to pathogens. Nat Rev Immunol 6:318-328. CrossRef Medline

Tanaka K, Furuyashiki T, Kitaoka S, Senzai Y, Imoto Y, Segi-Nishida E, Deguchi Y, Breyer RM, Breyer MD, Narumiya S (2012) Prostaglandin E2mediated attenuation of mesocortical dopaminergic pathway is critical for susceptibility to repeated social defeat stress in mice. J Neurosci 32 : 4319-4329. CrossRef Medline

Tynan RJ, Naicker S, Hinwood M, Nalivaiko E, Buller KM, Pow DV, Day TA, Walker FR (2010) Chronic stress alters the density and morphology of microglia in a subset of stress-responsive brain regions. Brain Behav Immun 24:1058-1068. CrossRef Medline

Vallières L, Sawchenko PE (2003) Bone marrow-derived cells that populate the adult mouse brain preserve their hematopoietic identity. J Neurosci 23:5197-5207. Medline

Wohleb ES, Hanke ML, Corona AW, Powell ND, Stiner LM, Bailey MT, Nelson RJ, Godbout JP, Sheridan JF (2011) $\beta$-Adrenergic receptor antagonism prevents anxiety-like behavior and microglial reactivity induced by repeated social defeat. J Neurosci 31:6277-6288. CrossRef Medline

Wohleb ES, Fenn AM, Pacenta AM, Powell ND, Sheridan JF, Godbout JP (2012) Peripheral innate immune challenge exaggerated microglia activation, increased the number of inflammatory CNS macrophages, and prolonged social withdrawal in socially defeated mice. Psychoneuroendocrinology 37:1491-1505. CrossRef Medline

Wohleb ES, Powell ND, Godbout JP, Sheridan JF (2013) Stress-induced recruitment of bone marrow-derived monocytes to the brain promotes anxiety-like behavior. J Neurosci 33:13820-13833. CrossRef Medline 